\title{
Pores distribution statistical analysis for metal foams obtained by casting-dissolution process
}

\author{
Melisa Cardona ${ }^{1}$, Jesica Andrea Isaza ${ }^{2}$ \\ Juan Fernando Ramírez ${ }^{2}$, Patricia Fernández-Morales ${ }^{3}$
}

\footnotetext{
${ }^{1}$ Universidad Nacional de Colombia, sede Medellín, Facultad de Minas. Carrera 64C No. 63 - 120. Medellín, Colombia. e-mail: mecardonata@unal.edu.co

2 e-mail: jaisaza@unal.edu.co,jframirp@unal.edu.co

${ }^{3}$ Universidad Pontificia Bolivariana, Facultad de Ingeniería Industrial. Circular 1ra. No. 70-01. Medellín, Colombia e-mail: patricia.fernandez@upb.edu.co
}

\begin{abstract}
Interesting properties of metal foams such as light weight, good energy absorption and low thermal conductivity, have promoted the development of new processes to improve properties without sacrificing productivity. This study aims to verify the uniformity pore distribution in an aluminum alloy foam obtained by Casting - Dissolution Process, using a nondestructive analysis. In order to evaluate mechanical properties of a metal foam using computational numerical models, the use of a small reconstructed section of the sample representing an entire volume of metal foam, was validated. In conclusion, it was possible to determine that all parts of the sample have the equivalent superficial area and volume.
\end{abstract}

Keywords: Metal foam, casting and dissolution process, porosity.

\section{INTRODUCTION}

Metal foams have several remarkable properties that make them suitable for many engineering uses. They are frequently used in different fields such as lightweight sandwich manufacturing, packaging and crashworthiness, because of their energy dissipation capability and their thermal and acoustical properties, which are still under study [1][2][3][4].

Different methods are proposed to get porous metals, starting from vapor phase on polymeric preforms, metal powder mixed with foaming agents, electrodeposited from an aqueous solution, injecting gas in the liquid metal or metal casting and infiltration on preforms [4][5]. It is known that the properties of metal foam and other cellular metal structures depend on the properties of the bulk metal as well as the homogeneity of the structural features such as: cell topology, relative density, cell size, cell shape and anisotropy, which in turn depend on the manufacturing method [6][7].

Several authors had shown limited number of methods to produce open cellular structures that allow obtaining uniform pore distribution. Zhao, et al. [8], developed the lost carbonate sintering process (LCS) for manufacturing metal foams with space holder technique and evaluated the cell structure using a visual analysis with SEM micrographs. They found the foam exhibits uniformly distributed open cells. Surace, et al. [7] implemented the Sintering-Dissolution Process (SDP), another space holder technique that uses watersoluble materials that allow controlling the cell shape, cell size and porosity. They measured the morphological parameters in a $2 \mathrm{D}$ cross section by an image software tool from the obtained samples that were longitudinally sawed cut with diamond blade [7].

Both, the foam structure and the pore morphology, depend on the fabrication method. In general, the SDP technic produces homogeneous foams, but it has not been established if every obtained sample has uniformly distributed pores, in a way that it can be concluded that a small portion of the sample is representative for all the volume in the mechanical response as well as in its geometry.

Thus, the aim of this work is to verify the pore distribution uniformity in an aluminum alloy foam obtained by Casting - Dissolution Process, using a nondestructive analysis, in order to validate the use of a small reconstructed section of the sample like a representative volume to evaluate mechanical properties of the metal foam using computational numerical models. 


\section{MATERIALS AND METHODS}

\subsection{Metal foam samples processing}

Casting-Dissolution Process was used to manufacture the aluminum foams. To make the preform, $\mathrm{NaCl}$ particles were sieved to obtain controlled sizes of $2.0 \mathrm{~mm}, 1.0 \mathrm{~mm}$ and $0.5 \mathrm{~mm}$, then they were put into a cylindrical steel mold, and finally were infiltrated with the AlSiMg liquid aluminum alloy under vacuum pressure and at temperature of $700^{\circ} \mathrm{C} . \mathrm{Al} / \mathrm{NaCl}$ composites of $10 \mathrm{~cm}$ in diameter and 8 in height were obtained. In order to reveal the porous structure, the salt was removed by water. This manufacturing method allows the porous to be present in all direction and with irregular shape replicated from the $\mathrm{NaCl}$ particles; so there is an inherent complexity in the structure geometry, where the porous are uniform but with random distribution.

\subsection{Visualization, segmentation and morphometry}

Different methods of visualization, segmentation and morphometry to analyze the geometry of foams are available. Due to the cell structure damage could be caused using destructive test, it was decided to do a nondestructive technique that allows to acquire detailed, quantitative, geometric datas from the three samples. $\mathrm{X}$-ray micro-computed tomography $(\mu \mathrm{CT})$ was employed to obtain the required images.

The $\mu \mathrm{CT}$ system used for the tomography of each sample consisted of a micro-focus $150 \mathrm{kV}$ Hamamatsu X-ray source with a tungsten target and a flat panel detector C7942. A $100 \mathrm{kV}$ filament voltage and a current of $100 \mu \mathrm{A}$ were used. Using a source-sample distance of $77.5 \mathrm{~mm}$ and a source-detector distance of $298 \mathrm{~mm}$, it was achieved a magnification factor of 3,8 and a pixel size $13 \mathrm{~mm}$. Additionally, the aluminum foams structure was examined by optical microscopy (Leica DMLM) and scanning electron microscope (JEOL JSM-6490LV SEM) to evaluate how the cells are interconnected.

Recent observations using X-ray $\mu \mathrm{CT}$ showed up the feasibility of the 3D reconstruction and basic measurements on X-ray tomography and prove that this technique is suitable for the investigation of the microstructure of foams, because it enables to obtain a real image of the inside [9],[10].

The X-ray $\mu \mathrm{CT}$ images were manipulated using specialized software, Mimics $\AA$, from which geometric information including strut length and pore shapes were extracted. Figure 1a. shows the 3D reconstruction from $\mu \mathrm{CT}$ and the Fig $1 \mathrm{~b}$. the SEM image for one of the samples.

(a)

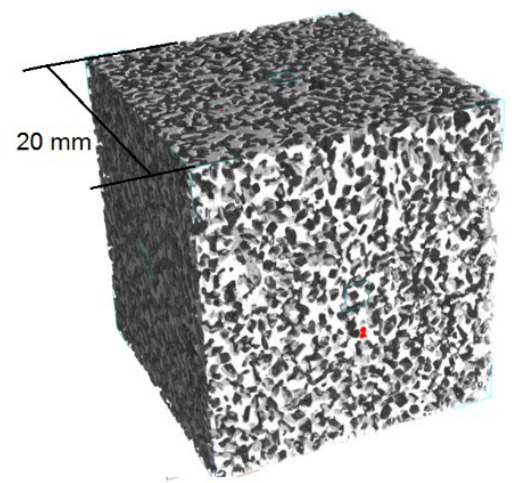

(b)

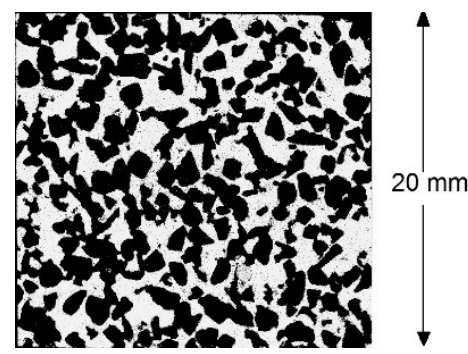

Figure 1: Sample with $0.5 \mathrm{~mm}$ pore size: (a) 3D reconstruct using Mimics ${ }^{\circledR}$ Materialise (b) Sample from SEM

\subsection{Porous distribution analysis}

As mentioned before, the major parameters to characterize the architecture of a cellular material are the global density and its fluctuation in the sample, the cell size distribution and the wall thickness distribution. In this sense, to determine if every obtained sample has uniformly distributed pores, a section of $99 \mu \mathrm{CT}$ image from each sample was imported to a 3D reconstruction using image analysis software, Mimics ${ }^{\circledR}$.

The reconstruction of the solid pore interface allows to extract every morphological three dimensional parameter: volume, surface area, aspect ratio, sphericity [9] and a comparison of these measures in every sample will allow to determine if homogeneity exist. In this work, given the geometrical complexity of the cells, the aspect ratio and sphericity of the pores was not measured, and instead of that, the volume and surface area of every metallic foam sample were obtained. 
The total analyzed images represent a volume of $20 \mathrm{~mm} \times 20 \mathrm{~mm} \times 10 \mathrm{~mm}$, a half of the actual size of the sample. Since the prime purpose is to obtain a minimum meshed volume able to be representative of the foam, the $\mu \mathrm{CT}$ slices were sectioned looking for a rectangular region that at least has a completed and defined pore. Using crop tool, the sample with $0.5 \mathrm{~mm}$ and $1.0 \mathrm{~mm}$ cell size were segmented into sixteen (16) parts, as shown in Figure 2, and four samples with $2.0 \mathrm{~mm}$ cell size were segmented into five (5) parts carrying out the same purpose, as shown in Figure 3.

Once the $3 \mathrm{D}$ reconstruction of every box section was made, the surface area and volume were measured using Mimics measure tools and from each parameter an average was calculated.

An experiment was designed to compare the homogeneity of every box section for each cell size and was implemented using Minitab ${ }^{\circledR}$ software. The experimental factor was the foam zone and the experimental response variables for the Analysis of Variance (ANOVA) were surface area and volume. Experimental factor (foam zone) was divided in three levels: 1 (corners), 2 (boundaries), 3 (center), for $0.5 \mathrm{~mm}$ and $1.0 \mathrm{~mm}$ cell size as shown in Figure 2. The experiment has more than one replicate for each level. Further, foam zone of $2.0 \mathrm{~mm}$ cell size was divided in five levels as in Figure 3. This segmentation ensures that there is at least one completed and defined pore in each part. Four 3D reconstruction of metal foam pore size $2.00 \mathrm{~mm}$ were carried out to ensure three replicates for each level.

\begin{tabular}{|l|l|l|l|}
\hline 1 & 2 & 2 & 1 \\
\hline 2 & 3 & 3 & 2 \\
\hline 2 & 3 & 3 & 2 \\
\hline 1 & 2 & 2 & 1 \\
\hline
\end{tabular}

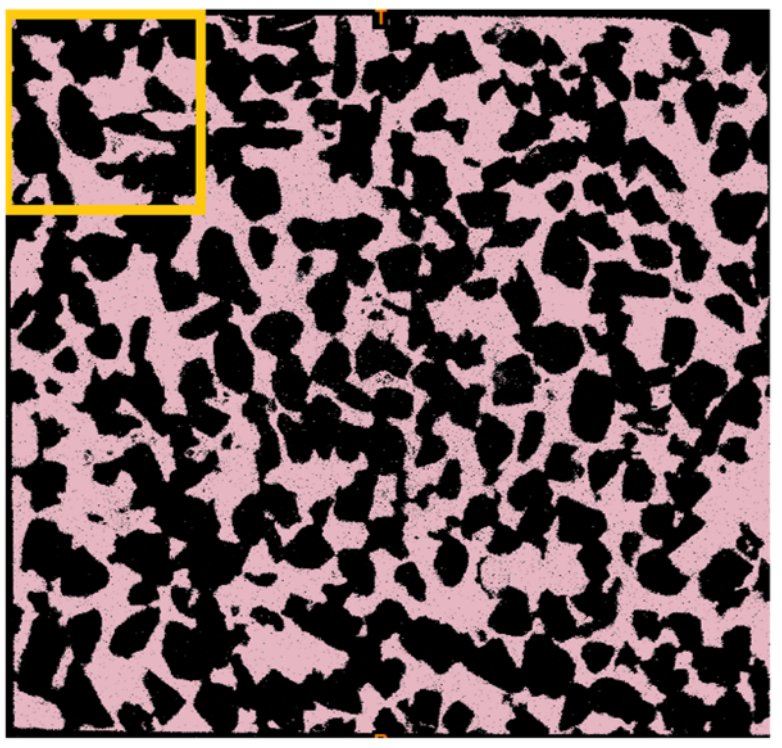

Figure 2: Sample segmentation foam with $1 \mathrm{~mm}$ cell size.
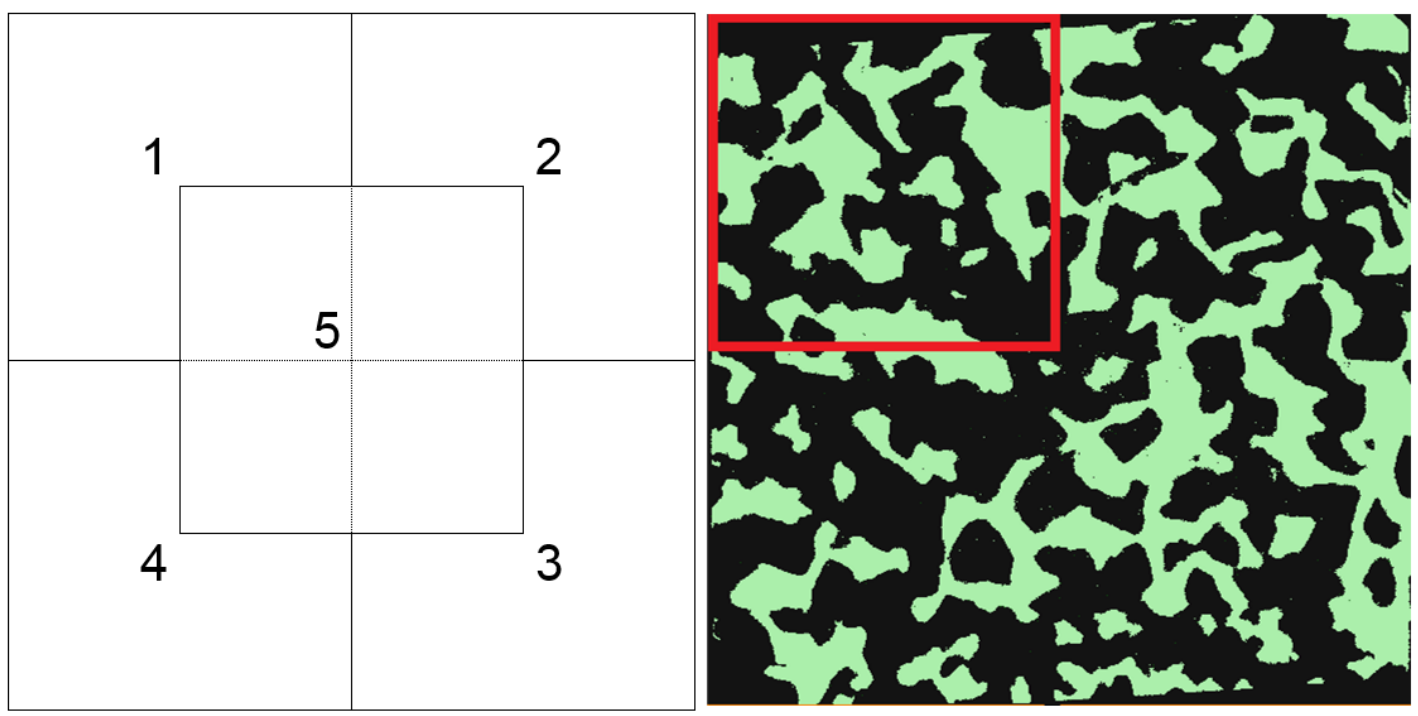

Figure 3: Sample segmentation foam with $2.0 \mathrm{~mm}$ cell size. 


\section{RESULTS}

Taking into account the benefits of the non-destructive test to probe complex porous structures, this study goes beyond using 3D reconstruction in order to get every morphological three dimensional parameter. It allows to acquire detailed, quantitative, geometric data from the three samples.

As shown in Figure 4, the reconstructed samples show that foams exhibit well-interconnected open cells. The pores have extensive elongation with a uniform distribution without accumulation in few regions.

(a)

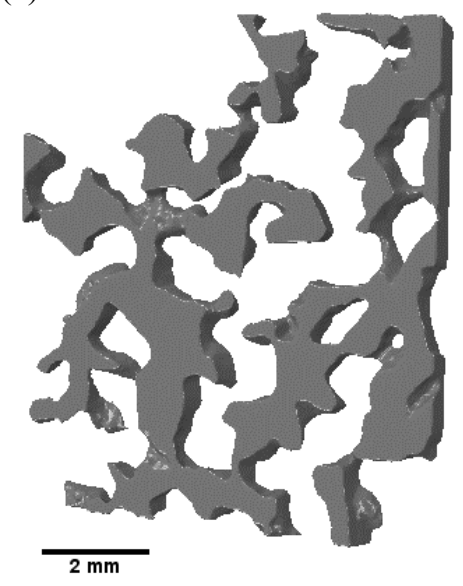

(b)

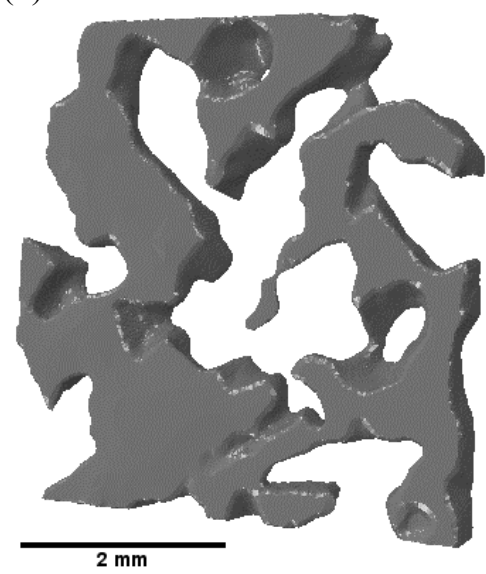

(c)

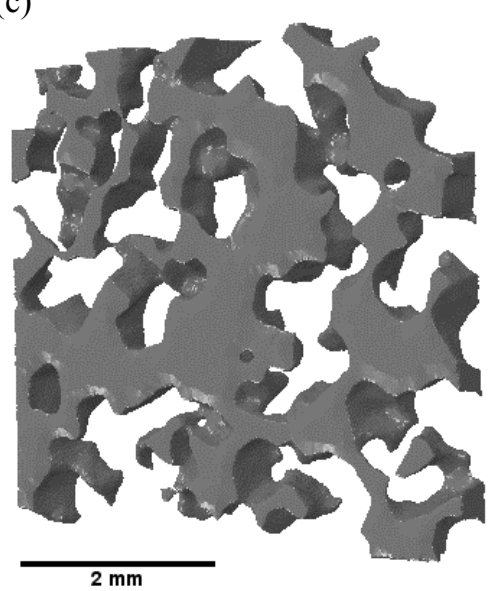

Figure 4: Reconstructed sample with (a). $2.0 \mathrm{~mm}$ cell size, (b). $1.0 \mathrm{~mm}$ cell size and (c). $0.5 \mathrm{~mm}$ cell size.

In addition, a visual inspection of the $\mu \mathrm{CT}$ shows that the obtained cell shape differs markedly from foams made by other methods starting from powders, as showed by B. H. Smith [4] in the micro-structure sample made by oxide ceramic foam precursor and made by powder metallurgy.

. Experiment design for $0.5 \mathrm{~mm}$ cell size can be observed in Table 1. The experiment response variables were surface area and volume for each sample $(0.5 \mathrm{~mm}, 1.0 \mathrm{~mm}$ and $2.0 \mathrm{~mm}$ cell size $)$, percentage difference is the comparison between the foam zone section area and volume with the average from each sample. In addition, Table 2 and Table 3 shows examples of ANOVA for $0.5 \mathrm{~mm}$ cell size, the first one has as response volume and the second one has surface area. From the analysis of variance (ANOVA) made with Minitab ${ }^{\circledR}$ it can be concluded that none of the factor levels are significant. The p-value reported is less than 0.05 for confidence percentage of $95 \%$, this means that there is no statistical evidence that shows no homogeneity in the foam. Additionally, box and whisker graphs shown in Figure 5 are useful for comparing groups of data and prove that there is not effect of foam zone. The assumptions of normal distribution, equal variances, and randomization of the residuals were checked to guarantee the validity of the experiment conclusions, respective graphs are shown in the Figure 6 and Figure 7.

Table 1: Volume, superficial area and percentage difference of the $0.5 \mathrm{~mm}$ cell size sample.

\begin{tabular}{l|l|l|ll|l}
\hline FOAM ZONE & VOLUME $\left[\mathrm{mm}^{3}\right]$ & AREA $\left[\mathrm{mm}^{2}\right]$ & $\begin{array}{l}\text { VOLUME PER- } \\
\text { CENTAGE } \\
\text { FERENCE }\end{array}$ & $\begin{array}{l}\text { AREA PERCEN- } \\
\text { TAGE DIFFE- } \\
\text { RENCE }\end{array}$ \\
\hline 3 & $1,376,994$ & 420,563 & $2 \%$ & $1 \%$ \\
\hline 3 & $1,347,223$ & 434,024 & $4 \%$ & $2 \%$ \\
\hline 2 & $1,374,366$ & 446,878 & $2 \%$ & $5 \%$ \\
\hline 2 & $1,489,473$ & 426,429 & $6 \%$ & $0 \%$ \\
\hline 2 & $1,364,214$ & 414,161 & $3 \%$ & $3 \%$ \\
\hline 3 & $1,431,615$ & 409,879 & $2 \%$ & $4 \%$ \\
\hline
\end{tabular}




\begin{tabular}{l|l|l|l|l}
\hline 2 & $1,524,831$ & 424,946 & $9 \%$ & $0 \%$ \\
\hline 1 & $1,415,271$ & 447,563 & $1 \%$ & $5 \%$ \\
\hline 1 & $1,416,070$ & 436,134 & $1 \%$ & $3 \%$ \\
\hline 3 & $1,222,860$ & 409,974 & $13 \%$ & $3 \%$ \\
\hline 1 & $1,473,876$ & 436,016 & $5 \%$ & $3 \%$ \\
\hline 2 & $1,337,973$ & 406,492 & $5 \%$ & $4 \%$ \\
\hline
\end{tabular}

Table 2: One-way ANOVA: Volume versus Foam zone.

\begin{tabular}{l|l|l|l|l|l}
\hline SOURCES & $\begin{array}{l}\text { DEGREE OF FRE- } \\
\text { EDOM }\end{array}$ & $\begin{array}{l}\text { SUM OF SQUA- } \\
\text { RES }\end{array}$ & MEAN SQUARES & FO & P - VALUE \\
\hline Foam zone & 2 & $3,812,363,001$ & $1,906,181,500$ & 0.29 & 0.756 \\
\hline Error & 13 & $86,755,014,663$ & $6,673,462,666$ & & \\
\hline Total & 15 & $90,567,377,664$ & & & \\
\hline
\end{tabular}

Table 3: One-way ANOVA: Area versus Foam zone.

\begin{tabular}{l|l|l|l|l|l}
\hline SOURCES & $\begin{array}{l}\text { DEGREE OF FRE- } \\
\text { EDOM }\end{array}$ & $\begin{array}{l}\text { SUM OF SQUA- } \\
\text { RES }\end{array}$ & MEAN SQUARES & FO & P - VALUE \\
\hline Foam zone & 2 & $411,432,113$ & $205,716,057$ & 1.13 & 0.354 \\
\hline Error & 13 & $2,373,939,890$ & $182,610,761$ & & \\
\hline Total & 15 & $2,785,372,004$ & & & \\
\hline
\end{tabular}

(a)

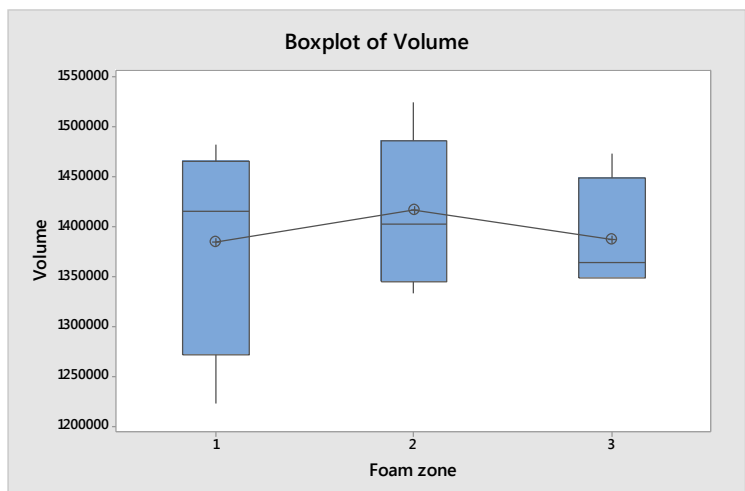

(b)

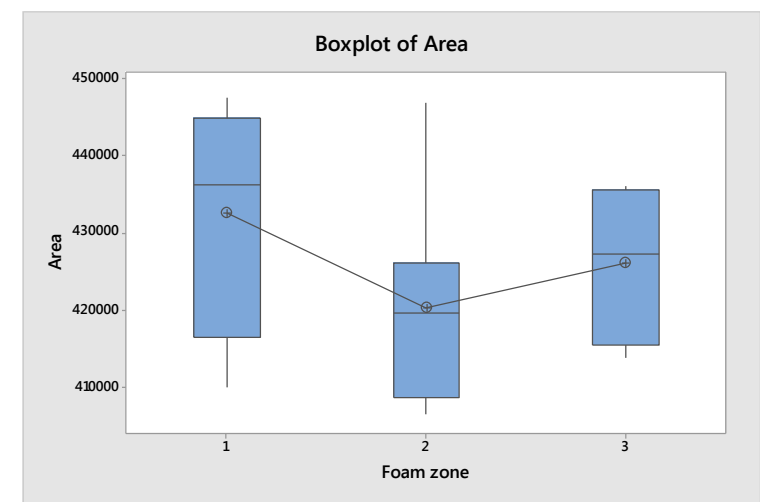

Figure 5: Box and whisker graphs: (a). Boxplot of Volume and (b). Boxplot of Area 


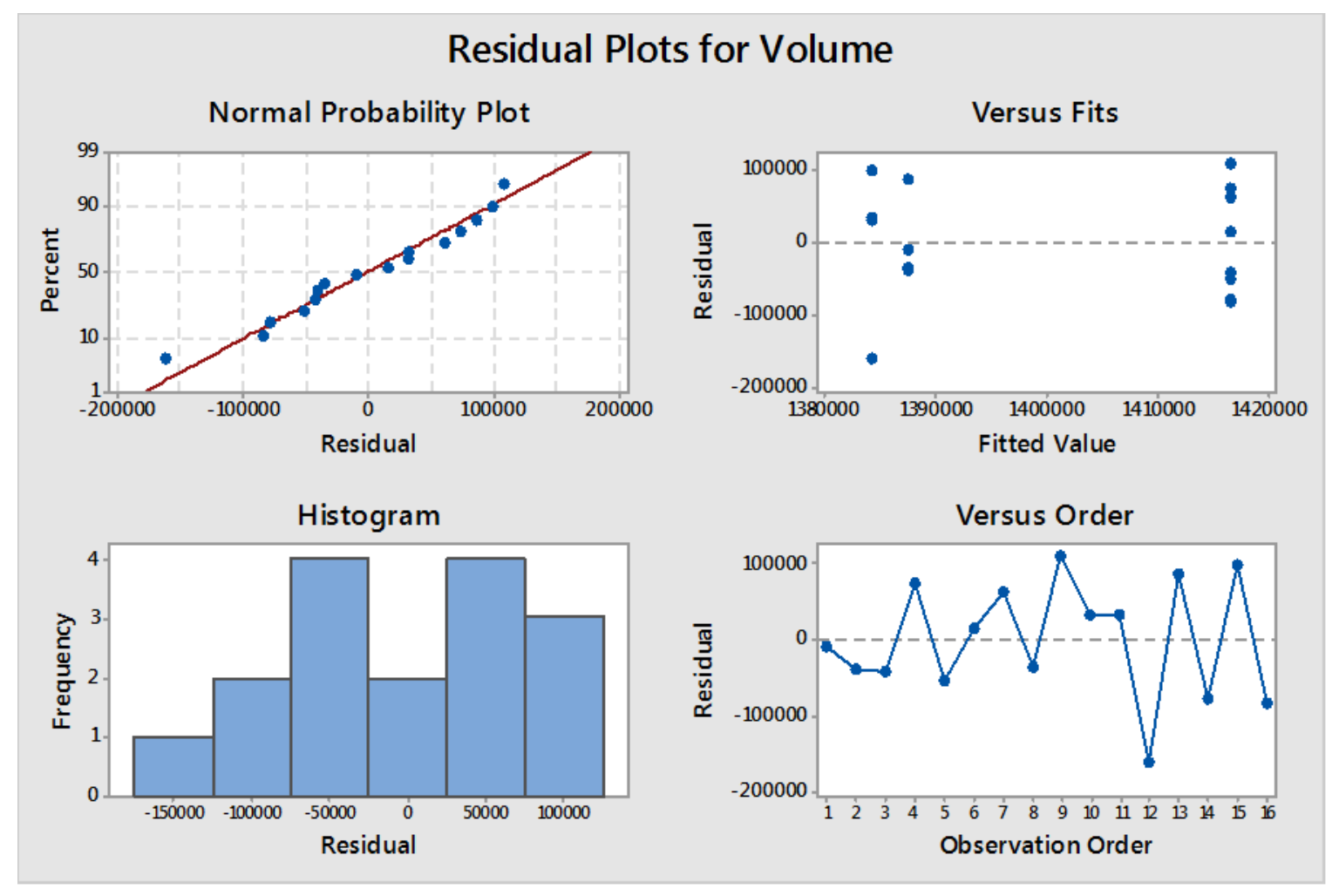

Figure 6: Residual plots for volume.

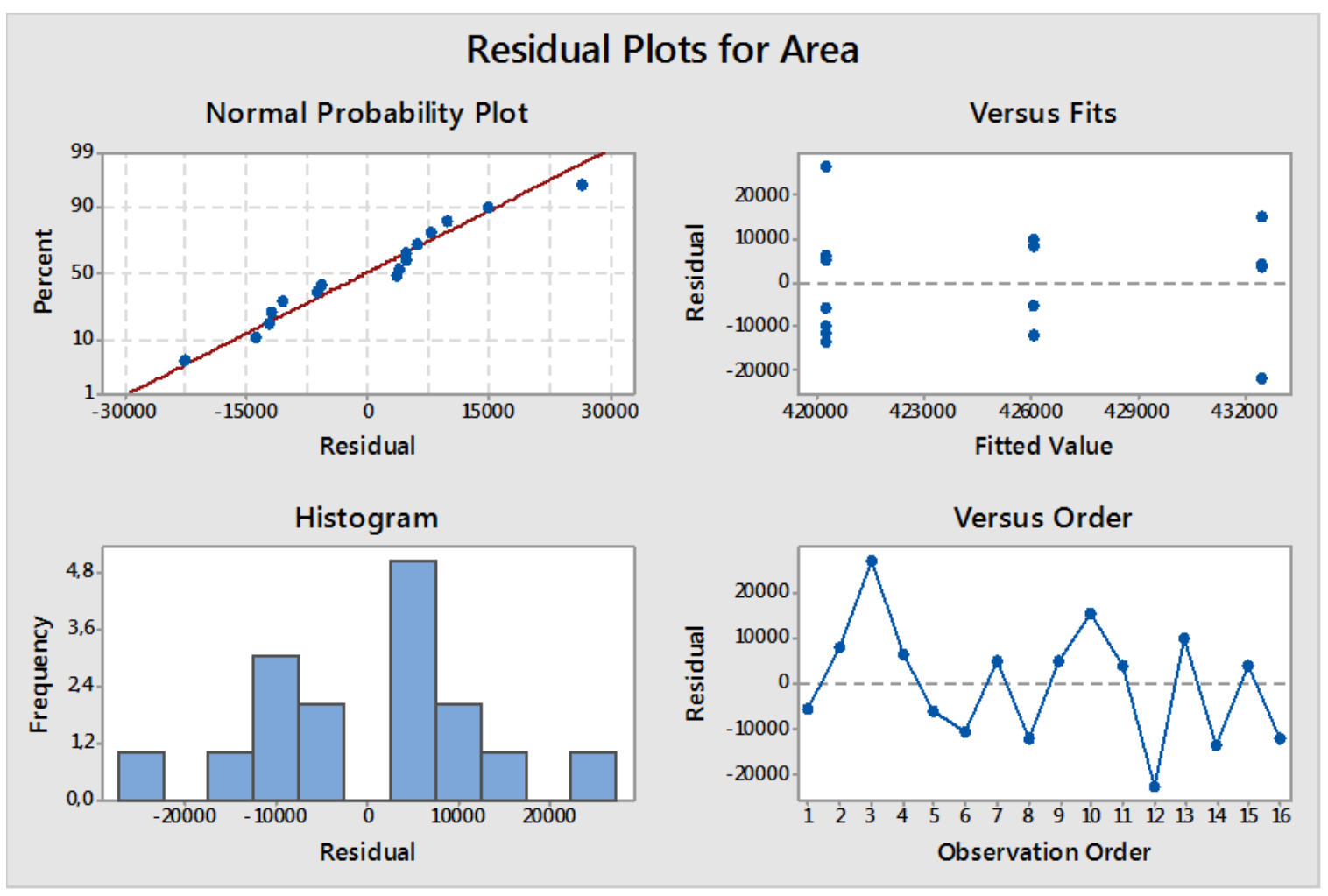

Figure 7: Residual plots for area.

Table 4 and Table 5 show experiment designs for $1 \mathrm{~mm}$ and $2 \mathrm{~mm}$ cell sizes, respectively. The assumptions of normal distribution, equal variances, and randomization of the residuals were checked to guarantee the validity of the experiment conclusions. Table 6 presents a summary of statistical analysis, where results show that all means are equal with a significance level $\alpha=0,05$. As a result, there is no 
statistical evidence that shows no homogeneity in the foam.

Table 4: Volume, superficial area and percentage difference of the $1.0 \mathrm{~mm}$ cell size sample..

\begin{tabular}{l|l|l|lr|l}
\hline FOAM ZONE & VOLUME $\left[\mathrm{mm}^{3}\right]$ & AREA $\left[\mathrm{mm}^{2}\right]$ & $\begin{array}{l}\text { VOLUME PER- } \\
\text { AREATAGE PERCEN- } \\
\text { DIF- }\end{array}$ & $\begin{array}{l}\text { TAGE } \\
\text { TIFFE- } \\
\text { RENCE }\end{array}$ \\
\hline 1 & $1,381,437$ & 273,793 & $2 \%$ & $4 \%$ \\
\hline 2 & $1,427,444$ & 265,326 & $1 \%$ & $7 \%$ \\
\hline 2 & $1,674,686$ & 273,444 & $18 \%$ & $4 \%$ \\
\hline 2 & $1,396,061$ & 284,243 & $1 \%$ & $0 \%$ \\
\hline 2 & $1,347,892$ & 264,490 & $5 \%$ & $7 \%$ \\
\hline 1 & $1,489,908$ & 302,619 & $5 \%$ & $7 \%$ \\
\hline 3 & $1,394,344$ & 297,361 & $1 \%$ & $5 \%$ \\
\hline 3 & $1,362,803$ & 265,482 & $4 \%$ & $6 \%$ \\
\hline 3 & $1,355,965$ & 267,758 & $4 \%$ & $6 \%$ \\
\hline 2 & $1,399,169$ & 293,909 & $1 \%$ & $4 \%$ \\
\hline 1 & $1,420,846$ & 296,198 & $0 \%$ & $4 \%$ \\
\hline & $1,493,212$ & 293,524 & $6 \%$ & $3 \%$ \\
\hline & $1,418,221$ & 292,444 & $0 \%$ & $3 \%$ \\
\hline & $1,375,053$ & 300,427 & $3 \%$ & $6 \%$ \\
\hline & $1,407,497$ & 309,392 & $0 \%$ & $9 \%$ \\
\hline
\end{tabular}

Table 5: Volume, superficial area and percentage difference of the $2.0 \mathrm{~mm}$ cell size sample..

\begin{tabular}{l|l|l|lr|l}
\hline FOAM ZONE & VOLUME $\left[\mathrm{mm}^{3}\right]$ & AREA $\left[\mathrm{mm}^{2}\right]$ & $\begin{array}{l}\text { VOLUME PER- } \\
\text { CENTAGE } \\
\text { FERENCE }\end{array}$ & $\begin{array}{l}\text { AREA PERCEN- } \\
\text { TAGE } \\
\text { RENCE }\end{array}$ \\
\hline 3 & $5,942,603$ & 856,090 & $4 \%$ & $3 \%$ \\
\hline 4 & $6,392,855$ & 823,117 & $12 \%$ & $1 \%$ \\
\hline 4 & $5,772,441$ & 796,834 & $1 \%$ & $4 \%$ \\
\hline 5 & $5,879,794$ & 930,776 & $3 \%$ & $12 \%$ \\
\hline 1 & $5,657,577$ & 860,088 & $1 \%$ & $3 \%$ \\
\hline 2 & $5,279,422$ & 831,757 & $7 \%$ & $0 \%$ \\
\hline 2 & $5,933,495$ & 863,018 & $4 \%$ & $4 \%$ \\
\hline 4 & $5,413,087$ & 860,690 & $5 \%$ & $3 \%$ \\
\hline 3 & $5,148,404$ & 802,194 & $10 \%$ & $4 \%$ \\
\hline 3 & $4,704,339$ & 700,987 & $18 \%$ & $16 \%$ \\
\hline 5 & $5,542,439$ & 846,233 & $3 \%$ & $2 \%$ \\
\hline 1 & $6,126,942$ & 796,116 & $7 \%$ & $4 \%$ \\
\hline & $5,416,844$ & 842,066 & $5 \%$ & $1 \%$ \\
\hline & $5,814,134$ & 823,313 & $2 \%$ & $1 \%$ \\
\hline & $5,570,315$ & 893,318 & $2 \%$ & $7 \%$ \\
\hline $5,804,712$ & 858,628 & $2 \%$ & $3 \%$ \\
\hline
\end{tabular}


Table 6: Summary of results.

\begin{tabular}{l|l|l|l|l}
\hline CELL SIZE & $\begin{array}{l}\text { EXPERIMENTAL } \\
\text { RESPONSE }\end{array}$ & MEAN & $\begin{array}{l}\text { STANDARD } \\
\text { DEVIATION }\end{array}$ & P-VALUE \\
\hline \multirow{2}{*}{$0.5 \mathrm{~mm}$} & Volume $\left[\mathrm{mm}^{3}\right]$ & $1,401,218$ & 77,703 & 0.756 \\
\cline { 2 - 5 } & Area $\left[\mathrm{mm}^{2}\right]$ & 424,781 & 13,627 & 0.354 \\
\hline \multirow{2}{*}{$1.0 \mathrm{~mm}$} & Volume $\left[\mathrm{mm}^{3}\right]$ & $1,413,867$ & 86,727 & 0.268 \\
\cline { 2 - 5 } & Area $\left[\mathrm{mm}^{2}\right]$ & 283,804 & 16,236 & 0.275 \\
\hline \multirow{2}{*}{$2.0 \mathrm{~mm}$} & Volume $\left[\mathrm{mm}^{3}\right]$ & $5,705,143$ & 402,076 & 0.629 \\
\cline { 2 - 5 } & Area $\left[\mathrm{mm}^{2}\right]$ & 833,286 & 54,679 & 0.374 \\
\hline
\end{tabular}

\section{DISCUSSION}

There are a number of studies on the effects of pore size on the mechanical properties of aluminum, titanium and magnesium and their alloy foams. It was found that the relationship between the compressive strength and the porosities is completely linear relation beyond the effect of pore size distributions on the mechanical properties [11]. Furthermore, it is worth noting that both the foam structure and the pore morphology depend on the fabrication method, utilized during manufacturing of the foams, which in turn determine the mechanical properties [12].

Several authors had shown limited number of methods to produce open cellular structures that allow obtaining uniform pore distribution [12]. In order to probe complex porous structures, high resolution X-ray computed tomography (XCT) or MRI techniques have been used in recent years. Bekoz et al [12], calculated the area of each pore on the SEM image and measured the pores size, shape and size distribution using Clemex Vision PE commercial image-analyzer software.

Saadatfar et al [13], used tomographic imaging technique to distinguish small changes in density, pore size distribution and pore geometry/topology of samples of different precursor sizes and geometries, made under gravity.

In this study, taking into account that usually cellular materials having small bubbles with uniform size and spherical shape are guarantee for better mechanical properties, it was found that despite of irregular morphology of pores; the high uniformity in pores distribution obtained with the evaluated process and the presence of numerous channels between the cells, makes CDP foams a sort of materials with oustanding mechanical properties.

\section{CONCLUSIONS}

The manufacturing and reconstruction process guarantee to obtain physical and virtual foams with a homogenous pore distribution.

It is widely accepted that foams with a uniform pore distribution and defects free, are desirable. It is worth noting that foams made by Casting - Dissolution Process provide uniform pore distribution in an aluminum alloy foam. Furthermore, all sections of metal foams are a representative sample of the entire volume and make useful to evaluate mechanical properties of the foam using computational numerical models, as it was proved by statistical method.

Due to the destructive test disturb the cell structure, 3D image analysis is a worthy method to extract a range of geometrical and topological properties including porosity, pore volume, size distribution and cell connectivity, which are directly measured on the images.

\section{BIBLIOGRAPHY}

[1] GRISHIN, A. A Mesh-Free Finite Element Solution for Unilateral Contact Problems, Ph.D, Arizona State University, Arizona, United States, 2010.

[2] JARILLO, J.M. Modelización del comportamiento mecánico de una espuma metálica, M. Sc. Universidad Carlos III de Madrid, Madrid, España. 2009.

[3] YOUSSEF, S., MAIRE, E., GAERTNER, R. "Finite element modelling of the actual structure of cellular materials determined by X-ray tomography”, Acta Mater., v. 53, n 3, pp. 719-730, Feb. 2005. 
[4] SMITH, B.H., SZYNISZEWSKI, S., HAJJAR, J.F., et al., "Steel foam for structures: A review of applications, manufacturing and material properties”, Journal of Constructional Steel Research, v 71, pp. 1-10, Apr. 2012.

[5] BANHART, J. "Manufacture, characterisation and application of cellular metals and metal foams". Progress in Materials Science, v 46, pp. 559-632, Jan 2001.

[6] PARVANIAN, A,M., SAADATFAR, M., PANJEPOUR, M, et al,. "The effects of manufacturing parameters on geometrical and mechanical properties of copper foams produced by space holder technique", Materials \& Design., v. 53, pp. 681-690, Jan. 2014.

[7] SURACE, R., FILIPPIS, L., LUDOVICO, A., et al, "Influence of processing parameters on aluminium foam produced by space holder technique”, Materials \& Design., v. 30, n. 6, pp. 1878-1885, Jun. 2009.

[8] ZHAO, Y.Y., FUNG, T., ZHANG, L.P., et al., "Lost carbonate sintering process for manufacturing metal foams”, Scripta Materialia., v. 52, n. 4, pp. 295-298, Feb. 2005.

[9] MAIRE, E., FAZEKAS, A., SALVO, L., et al., "X-ray tomography applied to the characterization of cellular materials. Related finite element modeling problems", Composites Science and Technology., v. 63, n. 16, pp. 2431-2443, Dec. 2003.

[10] BOCK, J., JACOBI, A.M., "Geometric classification of open-cell metal foams using X-ray micro-computed tomography”, Materials Characterization., v. 75, pp. 35-43, Jan. 2013.

[11] WANG, X., LI, J., HU, R., et al, "Mechanical properties of porous titanium with different distributions of pore size," Trans. Nonferrous Met. Soc. China, v. 23, no. 8, pp. 2317-2322, Aug. 2013.

[12] BEKOZ, N., OKTAY, E. "Mechanical properties of low alloy steel foams: Dependency on porosity and pore size,” Mater. Sci. Eng. A, v. 576, pp. 82-90, Aug. 2013.

[13] SAADATFAR, M., GARCIA-MORENO, F., HUTZLER, S., et al, "Imaging of metallic foams using Xray micro-CT,” Colloids Surfaces A Physicochem. Eng. Asp., vol. 344, no. 1-3, pp. 107-112, Jul. 2009.

[14] JAKUBOWICZ, J., ADAMEK, G., PAŁKA, K., et al, "Micro-CT analysis and mechanical properties of Ti spherical and polyhedral void composites made with saccharose as a space holder material", Mater. Charact., v. 100, pp. 13-20, Feb. 2015 